\title{
OBITUARY
}

\section{CLARENCE B. HUTCHINGS, 1877-1945}

It is with sorrow that we record the death of Clarence Basden Hutchings, which occurred on October 30, 1945. Born in Hamilton, Bermuda, on August 28, 1877, he did not come to Canada until about 1902. Prior to this he spent some time in England. In 1916, he graduated from Macdonald College (affiliated with McGill University) with the degree of B.S.A.

For a period of about 27 years he was a valued officer of the Entomological Branch of the Dominion Department of Agriculture. He entered the Service in 1916, as a field assistant in the Division of Forest Insects. Later his title was changed to Assistant Entomologist. For approximately ten years he was in charge of a summer forest insect laboratory at Aylmer, Que. During these years observations were conducted on important insect pests, particularly the bronzed birch borer, Agrilus anxius Gory, the lesser oak carpenter worm, Prionoxystus macmurtrei (Guer.), the locust borer, Cyllene robiniae (Forst.), the birch leaf skeletonizer, Bucculatrix canadensisella Chamb., and the lilac leaf miner, Gracilaria syringella (Fab.). Resulting from these and other studies several Branch publications were issued, namely, "The Walnut Caterpillar and Its Control", (Ent. Br. Cir. No. 21, 1924); "The Lesser Oak Carpenter Worm and Its Control", (Ent. Br. Cir. No. 23, 1924) ; and "The Important Shade Tree Insects of Eastern Canada and Their Control", joint authorship with J. M. Swaine (Dept. Agr. Bull. No. 63, new series, 1926) .

In 1927, Hutchings was transferred from the Division of Forest Insects to the Administration Division to take charge of the exhibition work of the Branch under the immediate direction of the Dominion Entomologist. This included the development and arranging of attractive and educational exhibits for display at the Canadian National Exhibition, Toronto; the Central Canada Exhibition, Ottawa; the Royal Winter Fair, Toronto; the Western Fair, London; the Quebec Exhibition, Quebec, and a number of smaller fairs, particularly in Eastern Canada. At the World's Grain Exhibition held in Regina, Sask., in 1933, specially prepared exhibits of grain-destroying insects were displayed. Attractive entomological exhibits were also shown at annual meetings of the Canadian Pulp and Paper Association, rural youth training schools, etc. Under Hutchings, the exhibition work of the Branch developed to a high degree. He experienced great pleasure in contributing information of value to the general public, as a result of which he made numerous friends. Many thousands of enquiries were received regarding insect pests. He certainly gave of his best. F. C. Nunnick who directs the general exhibition work of the Dominion Department of Agriculture, expressed on several occasions the admiration he had for the care and courtesy shown by Hutchings as officer in charge of Entomological Branch exhibits.

From 1929, Hutchings assisted the writer in the preparation of insect exhibits for the National Museum of Canada at Ottawa. By 1940, no less than 96 special cases had been prepared and placed on exhibit in the Museum. These have attracted much attention from the general public.

During the winter of 1935 he assisted the Dominion Entomologist in greenhouse insect investigations. Ninety-eight greenhouses in Ontario were visited and notes taken on prevalent pests.

In addition to his entomological work, Hutchings took a real interest in the activities of the Entomological Society of Ontario and the Ottawa FieldNaturalists' Club, in both organizations of which he held office. He was also for some years a member of the Canadian Society of Technical Agriculturists and more recently of the Professional Institute of the Civil Service of Canada.

He was a true lover of flowers and in the gardens which he developed, along with his wife, he found much happiness. In music too, he experienced great delight. Many a happy hour was spent in listening to the better symphonies. 
In his official work in the Entomological Branch, Hutchings served faithfully and well, as a result of which he was promoted, in 1937, to the position of Entomologist. He retired from the service on March 20, 1943. To his wife we extend our sincere sympathy.

Clarence, as he was known to most of us, added much to our knowledge of forest and shade tree insects. In addition to the departmental publications mentioned, other entomological contributions were published, as follows:

"Two Destructive Shade Tree Borers", Rep. Que. Soc. Prot. of Plants, 1917

"The Imported Alder Leaf Miner", Rep. Que. Soc. Prot. of Plants, 1919.

"Notes on Walkingsticks", Can. Ent., Vol. 52, No. 9, 1920.

"A Compilation of the Writings of Late C. Gordon Hewitt", Can. Ent. Vol. 52, May, 1920.

"Some Biological Observations on the Bronze Birch Borer", Rep. Que. Soc. Prot. of Plants, 1922.

"Notes on the Biology of Two Buprestids Infesting Blackberry and Hazel”, Rep. Ent. Soc. Ont. 1922.

"A Study of the Pupal Case of Prionoxystus macmurtrei G.-M.", Rep. Ent. Soc. Ont., 1923

"Life-History, Habits and Control of the Lesser Carpenter Worm", Rep. Que. Soc. Prot. of Plants, 1923

"Note on the Monarch Butterfly with Reference to its Migratory Habits", Can. Field Nat., Vol. 37, 1923.

"Two Important Insect Enemies of the Maple", 17th Ann. Rep. Que. Soc. Prot. of Plants, 1924. "Report on Insects of the Year, Division No. 1", 55 th Ann. Rep. Ent. Soc. Ont., 1924.

"The Lilac Leaf Miner, Gracilaria syringella Fab.", 55th Ann. Rep. Ent. Soc. Ont., 1924.

"Shade Tree Insects of Eastern Canada for the Year 1925 with Remarks on Their Activities and Prevalence", Rep. Que. Soc. Prot. of Plants, 1925.

"The Birch Leaf Skeletonizer, Bucculatrix canadensisella Chamb.", Ann. Rep. Ent. Soc. Ont. 1925.

"The Lilac Miner", Canadian Florist, March, 1925.

"Insects of the Season, Ottawa District", Ann. Rep. Ent. Soc. Ont., 1925.

"A Study of the Hazel Nut Weevil, Balaninus obtusus Blanch." 57 th Ann. Rep. Ent. Soc. Ont., 1926.

"Report of Insects for the Year, Division No. 1", 57th Ann. Rep. Ent. Soc. Ont., 1926.

"Report of Insects of the Year, 1927," 58th Ann. Rep. Ent. Soc. Ont., 1927.

"Rose Garden at McKellar, 'Bronwylfa",, Ann. Rep. Rose Society of Ont., 1927.

"An Enemy of the Lilac", Que. Soc. Prot. Plants 20th Ann Rep., 1927-28; 1928.

"Some Note on the Praying Mantis", Can. Field Nat., Vol. XLVIII, 1934.

Arthur Gibson.

\section{GUELPH PRINTING SERVICE}

Mailed Thursday, May 23, 1946. 